DRAFT. NOT FOR QUOTATION OR COPYING.

\title{
Intonation in European and Brazilian Portuguese
}

\author{
Sónia Frota ${ }^{1} \&$ João Antônio de Moraes ${ }^{2}$ \\ 1 Universidade de Lisboa, ${ }^{2}$ Universidade Federal do Rio de Janeiro/CNPq
}

\section{Introduction: Intonation and its functions in Portuguese}

Intonation is the use of phonetic features, namely pitch, to express phrase-level meanings in ways that are linguistically structured (Gussenhoven 2007, Ladd 2008, a.o). The roles played by intonation in language have long been described in terms of three main functions of intonation (e.g. Halliday 1967): demarcation, that is the chunking or phrasing of the speech stream into intonation-based units; highlighting, that is the placement of prominence within an utterance; and the distinction of utterance types, i.e. statements, questions, imperatives, vocatives. Grammaticalizations of all or some of these functions may be found in different languages, with different realizations, and define the language-specific phonology of intonation. In this chapter, we describe the intonation system of Portuguese, concentrating on the analysis of the three main functions of intonation. The framework adopted is the auto-segmental metrical theory of intonational phonology (e.g., Gussenhoven 2004; Ladd 2008; Jun 2005, 2014), along the lines of previous descriptions of the intonation of Brazilian and European Portuguese (Viana 1987; Frota 1997, 2000, 2002, 2014; Mata 1999; Frota \& Vigário 2000, 2007; Tenani 2002; Fernandes 2007a,b; Moraes 2008; Serra 2009, inter alia) ${ }^{1}$.

We begin by the chunking function of intonation in section 2 , where intonational phrasing in Portuguese is described. Tonal marking of intonational phrases is discussed, as well as the distribution of tonal events within the intonational phrase. Other levels of prosodic phrasing that are intonationally relevant are also discussed.

Section 3 addresses the highlighting function of intonation in Portuguese, namely the strategies used to mark focus prosodically. Several strategies are discussed, like pitch accent placement, pitch accent type, phrasing markers, expanded pitch range for the focal accent, pre-focal and post-focal deaccenting or pitch range compression.

Section 4 is devoted to the contribution of intonation to sentence type distinctions. The nuclear contours of four main sentence types are described: statements, questions (wh-questions and yes-no questions), imperatives (commands and requests), and vocatives (greeting call and insistent call). Together with a basic intonational inventory of pitch accents and boundary tones, other key features of the intonation system of Portuguese are discussed, namely the ways the language explores tonal alignment to convey meaning distinctions and the preferred tune-text accommodation strategies.

Unless otherwise stated, the present chapter is based on the description of a single variety: the Lisbon variety for European Portuguese (hereafter EP), and the Rio de Janeiro variety for Brazilian Portuguese (hereafter BP). In section

\footnotetext{
${ }^{1}$ Other work on the intonation of Portuguese within different frameworks of analysis includes Cruz-Ferreira 1998, Moraes 1998, and Lucente 2012.
} 
5, we provide a summary description of the main dimensions of variation across varieties of Portuguese, covering the data available for different European and Brazilian varieties.

Finally, section 6 discusses the intonation of Portuguese within the Romance space, from a typological perspective.

\section{Intonation and phrasing}

One of the key functions of intonation is the division of the speech stream into prosodic units. Intonation is one of the ways in which the prosodic structure of an utterance manifests itself (together with timing patterns and variations in segmental variation), and thus provides relevant cues to the grouping/demarcation of the prosodic units that characterize spoken utterances. Importantly, the organizational structure of spoken utterances is not entirely predictable from their syntactic structure, depending on the phonological grammar of the language and the particular choices made by the speaker among the possibilities available for a given utterance (Shattuck-Huffnagel 1996; Nespor and Vogel 2007; Wagner \& Watson 2010). In this section, we describe the language-particular preferences in intonational grouping that characterize European and Brazilian Portuguese, the size of intonational phrases, the distribution of tonal events within the intonational phrase and the ways in which intonational boundaries are realized. Although the intonational phrase is the prosodic unit under analysis, other levels of prosodic phrasing that are intonationally relevant in Portuguese are also discussed.

The intonational phrase (IP) is the prosodic constituent that constitutes the domain for the intonation contour (Nespor \& Vogel 2007), in other words it necessarily contains one and only one nuclear contour. In stress languages like English and Portuguese, the nuclear contour is the melody on the nuclear syllable and subsequent post-tonic syllable(s). In most Romance languages nuclear prominence is rightmost within the IP (Nespor \& Vogel 2007; Ladd 2008). Beyond this general definition of the IP, which fully applies to Portuguese, European and Brazilian Portuguese differ in important ways with respect to intonational phrases.

One of the main differences between EP and BP concerns the intonational characterization of the IP. In EP, only the head of the IP needs to be pitch accented and only the right-edge of the IP requires tonal boundary marking (Frota 2000, 2014). In BP, almost every prosodic word is pitch accented (Frota \& Vigário 2000; Tenani 2002; Fernandes 2007b; Tenani \& Fernandes-Svartman 2008; Vigário \& Fernandes-Svartman 2010). This is illustrated by the sparse pitch accentuation of the rendition of the five prosodic word utterance in Figure 1 by an EP speaker in contrast with the rich pitch accentuation of a similar utterance produced by a BP speaker. 

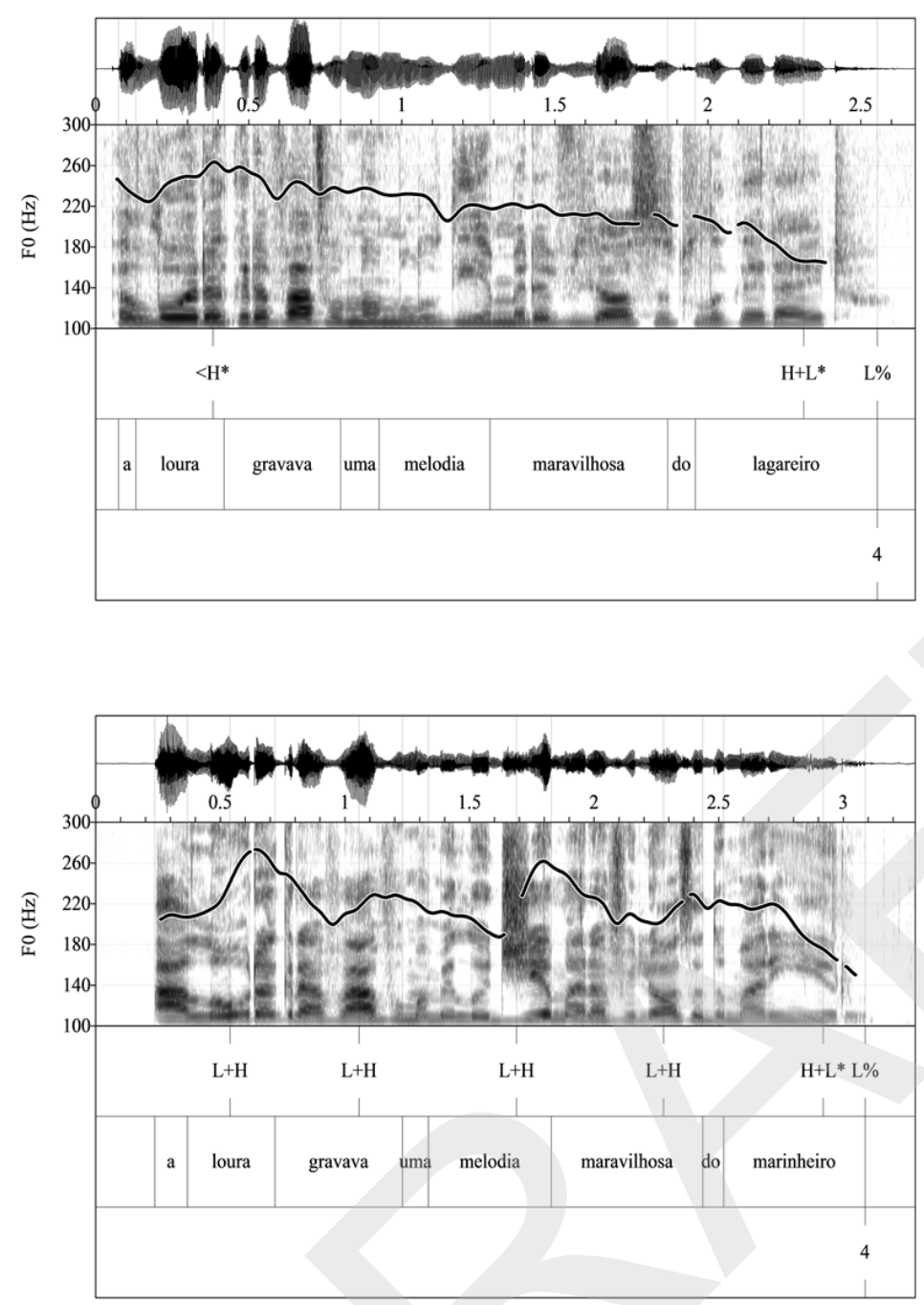

Figure 1. F0 contour of the utterance $A$ loura gravava uma melodia maravilhosa do lagareiro/marinheiro ('The blond girl recorded a wonderful song from the olive-pressman/sailor'), produced by an EP speaker (top panel) and a BP speaker (bottom panel)

Thus, in EP tonal events, pitch accents included, mostly occur near the edges of intonational phrases, and phrase-internal prosodic words are frequently unaccented. Tonal events have therefore a demarcative function signalling intonational phrasing. In BP, by contrast, tonal events tend to characterize prosodic words and cue prominent syllables. However, in EP as in BP intonational phrase boundaries are usually signalled by a continuation rise contour (a rising accent LH followed by a high boundary tone) if utteranceinternal, although a low boundary tone can also be found (Frota 2000; Tenani 2002; Frota, D’Imperio, Elordieta, Prieto \& Vigário 2007; Serra 2009)

The division of utterances into intonational phrases has been extensively studied for EP on the basis of neutral declarative sentences containing a subject, a verb and an object, in that linear order (Elordieta, Frota \& Vigário 2005; Frota \& Vigário 2007). It was found that the intonational phrasing of SVO in a single IP prevails, yielding relatively long phrases containing four or more prosodic 
words. Although parallel studies are not yet available for BP, recent data from the Interactive Atlas of the Prosody of Portuguese Project (Frota 2012-2015) suggest that phrasing preferences in BP promote shorter phrases in equivalent contexts, as shown in Figure 2.

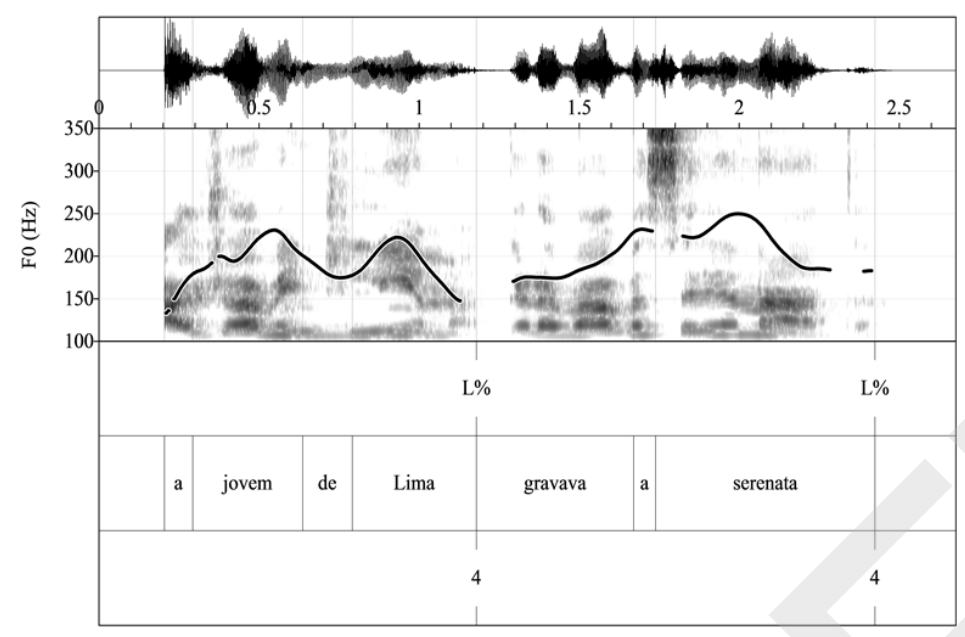

Figure 2. F0 contour of the utterance $A$ jovem de Lima gravava a serenata ('The young woman from Lima recorded a serenate'), produced by a BP speaker.

Portuguese has been described has having only one level of prosodic phrasing relevant for intonational structure: the intonational phrase. This means that prosodic phrases smaller than the intonational phrase do not exhibit tonal boundary marking (Frota 2000, 2002; Tenani 2002; Moraes 2008). However, unlike in EP, in some descriptions of BP (São Paulo variety) narrow focus may be manifested by the presence of a low phrase boundary associated to the right edge of the phonological phrase that contains the focused element (Fernandes 2007a; Tenani \& Fernandes-Svartman 2008). In this pragmatic context, tonal boundary marking may function as a demarcation cue in BP, signaling a level of prosodic phrasing lower than the intonational phrase. Prosodic focus in Portuguese is the topic of the following section.

\section{Intonation and focus}

It is known that languages with word stress tend to have postlexical pitch accents (Jun 2005). This generalization could be extended to include the likelihood of stress languages to grammaticalize the highlighting function of intonation. In these languages, prominence at the intonational phrase level tends to be realized culminatively by means of a pitch accent, which is the nuclear pitch accent within the prosodic phrase, and nuclear pitch accent location reflects the intended focus of the utterance. Portuguese is a stress language that uses intonation as a device to express focus.

Focus is here understood as the most important part of an utterance. There are several theories of focus and various definitions of types of focus (e.g., Krifka 2007; Ladd 2008; Wagner \& Watson 2010). Two types of focus are usually distinguished: (i) narrow focus, which indicates the contribution, in terms of new 
(or more relevant) information made in utterance, and (ii) contrastive focus, which explicitly contradicts a previous assertion or presupposition. In the former, focus identifies the part of the answer that corresponds to the wh-part of a question; In the latter, focus leads to a corrective interpretation of a previous proposition. The domain or size of the focus constituent may also vary, distinguishing narrow and contrastive focus from broad focus. In the narrow and contrastive focus cases the domain is typically a single word or a short constituent. In broad focus cases a larger constituent or the whole utterance is the focus.

In Portuguese, focus can be implemented by syntactic, morphological or prosodic devices, or by a combination of them. For example, the inversion of the canonical word order can be used as a mechanism to express contrastiveness, as in Elegante está você (canonical order Você está elegante), rendered in English by a cleft sentence 'It is you that is stylish'. Cleft structures can also be used in Portuguese, as in the expression Eu é que agradeço ('I am the one that is grateful', implying me, not you). The same interpretation can be achieved by the assignment of prosodic prominence to the utterance's subject ' $E u$ ', as in $E U$ agradeço ( 'I thank you'). In this section, we describe the strategies used in Portuguese to mark focus prosodically, concentrating on utterances with narrow and contrastive focus. For the intonational analysis of Portuguese, and along the lines of previous work on EP and BP (Frota 2000, 2002, 2014; Frota \& Vigário 2000; Tenani 2002; Fernandes 2007a,b; Moraes 2008; Frota et al. in press), we recognize two main types of tonal events: pitch accents, which may be simple or complex (i.e., monotonal like $\mathrm{L}^{*}$ or bitonal like $\mathrm{L}^{*}+\mathrm{H}$ ), and boundary tones, peripherally associated to intonational phrase edges and that may also be simple or complex events (e.g., L\% or LH\%).

\subsection{Focus in statements}

Previous work on prosodic focus in statements shows that pitch accent placement is a robust strategy to signal focus in Portuguese, but the choice of pitch accent may differ in EP and BP.

In EP, narrow focus, whether contrastive or not, is expressed by similar pitch contours: a falling pitch accent with the peak on the stressed syllable of the focalized element immediately followed by a fall (Frota 1997, 2000, 2002, 2014; Vigário 1998; Fernandes 2007b; Frota et al. in press). Figure 3 illustrates the focus contour in narrow and contrastive focus contexts (top and middle panels panels versus bottom panel), and in late and early focus position in the sentence (top panel versus middle and bottom panels). 

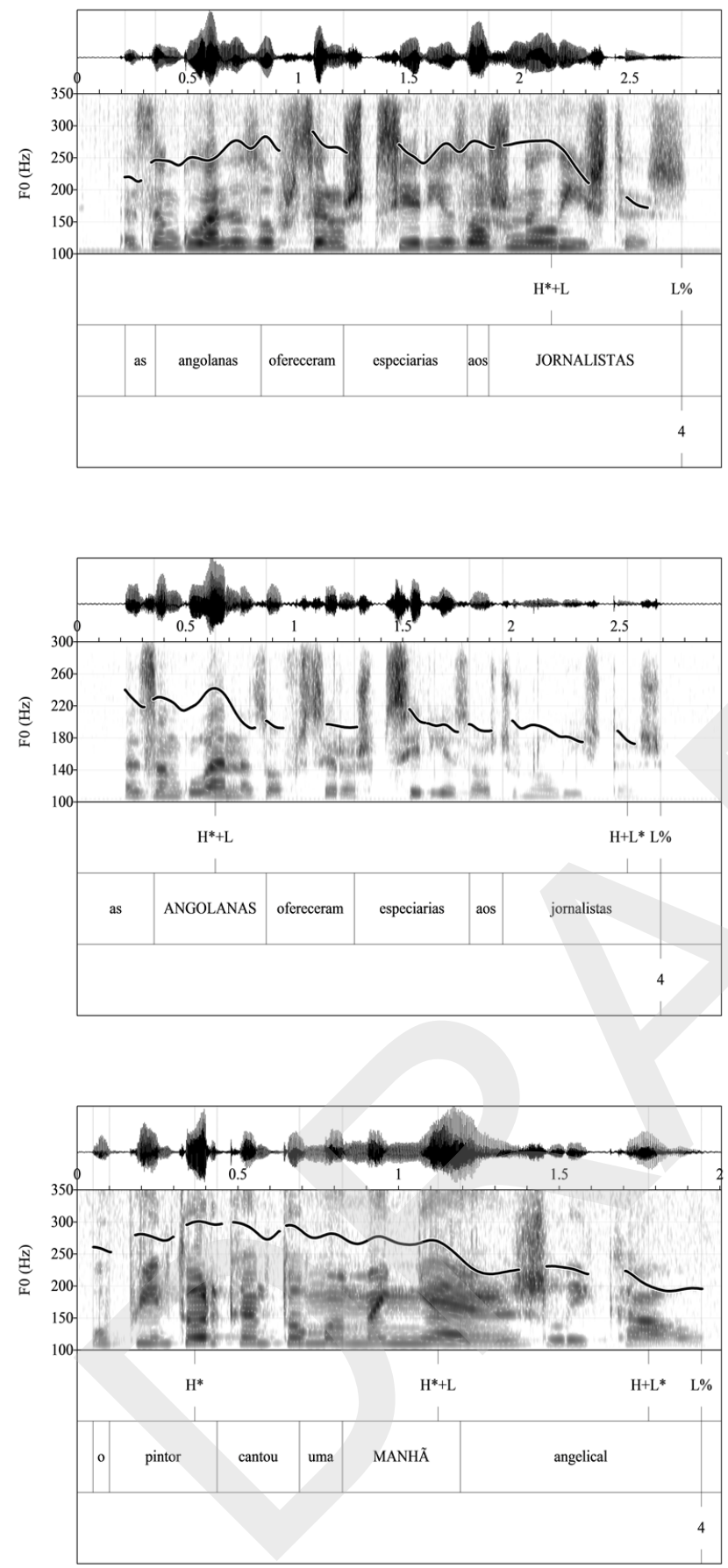

Figure 3. F0 contour of the utterance As angolanas ofereceram especiarias aos jornalistas ('The Angolan girls offered spices to the journalists'), with a narrow focus on 'aos jornalistas' (in response to 'Whom did they give spices to?'), in the top panel, and with a narrow focus on 'as angolanas' (in response to 'Who offered spices to the journalists?'), in the middle panel. F0 contour of the utterance $O$ pintor cantou uma manhã angelical, with a contrastive focus on 'manhã' (in response to 'Was it an angelic night that the artist sang?'), in the bottom panel.

The focus contour has been analyzed as showing a $\mathrm{H}^{*}+\mathrm{L}$ pitch accent, which contrasts with the nuclear fall that characterizes neutral (broad focus) 
statements where the peak is located in the pre-nuclear syllable $\left(\mathrm{H}+\mathrm{L}^{*}\right.$, see section 4). Importantly, narrow/contrastive focus is also signaled by lengthening, whereas peak height was not found to be a robust cue of focus across speakers (Frota 2000). The systematic contrast between $\mathrm{H}^{*}+\mathrm{L}$ and $\mathrm{H}+\mathrm{L}^{*}$ revealed in production data was also found to play a role in perception. Frota (2012) provides experimental evidence that the difference in the alignment pattern of HL is enough to trigger a perceptual change between a neutral and a narrow/contrastive focus interpretation.

Besides the presence of a special pitch accent as a strategy to signal focus, pitch range compression is also a focus marker in statements with an early focus. The postnuclear stretch shows a compressed pitch range, which enhances the nuclear prominence of the focused element, as illustrated in Figure 3 (panels B and C). However, there is no deaccenting in the postnuclear contour. A postnuclear accent on the last stressed syllable of the IP is usually found, but with reduced range, as shown in Figure 3 (Frota 2000, 2002a, 2014). Pre-focal pitch range compression, unlike post-focal one, has not been documented in EP. The presence of a narrow or contrastive focus in an utterance was also not found to impact on the prosodic and intonational phrasing of that utterance that remains similar to its neutral counterpart (Frota 2000, 2002b).

In $\mathrm{BP}$, there seems not to be a single pitch accent type associated with the expression of focus. In addition, some studies have reported that narrow and contrastive focus are conveyed by similar pitch contours (Truckenbrodt, Sândalo \& Abaurre 2009), while other reported differences between the two types of foci (Moraes 2006a).

Differently from EP, narrow focus in final position presents a low fall nuclear contour, characterized by a F0 peak on the syllable preceding the final stressed syllabe of the utterance (belonging or not to the same word) and a fall on the stressed syllable (Moraes 2008, Truckenbrodt et al. 2009). This contour, illustrated in Figure 4 (top panel), is analysed as a $\mathrm{H}+\mathrm{L}^{*}$ pitch accent and does not differentiate a statement with a late narrow focus from a neutral statement, which also has $\mathrm{H}+\mathrm{L}^{*}$ as the nuclear accent (see section 4). If the final focus is contrastive, the $\mathrm{H}+\mathrm{L}^{*}$ pitch accent can show expanded pitch range, as in Figure 4 (middle panel). The contrastive focus pattern is thus characterized by a rise to an extra-high level on the pre-nuclear syllable and a fall to a low level on the stressed syllable of the focused word. The focused word also presents an increase in duration and in intensity, mainly in the stressed syllable, features which play an important role in the identification of this pattern (Barbosa 2012; Moraes 2008).

Unlike in Moraes (2008), where the Rio de Janeiro variety is described, in Truckenbrodt et al. (2009)'s description of the São Paulo variety no F0 height differences are reported between late narrow and contrastive focus, which are expressed by the $\mathrm{H}+\mathrm{L}^{*}$ nuclear accent. These findings may suggest regional differences in the implementation of the contrastive focus pattern, but further research is needed to clarify this point. 

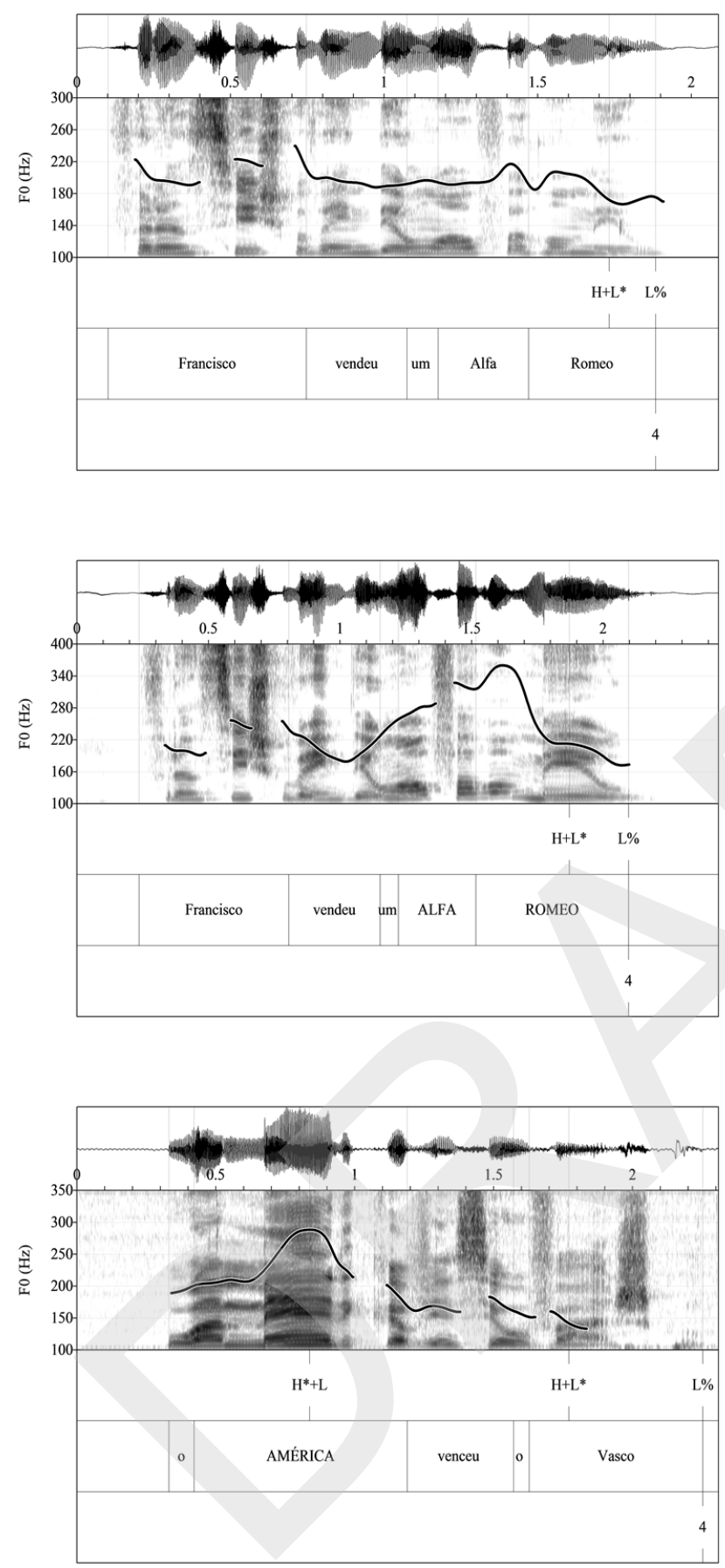

Figure 4. F0 contour of the utterance Francisco vendeu um Alfa Romeo ('Francisco sold an Alfa Romeo'), with narrow focus on 'Alfa Romeu' (in response to 'What car Francisco sold yesterday?'), in the top panel, and with contrastive focus on 'Alfa Romeu' (in response to the previous utterance 'Francisco sold a Porsche'), in the middle panel. The utterance $O$ América venceu o Vasco ('América has beaten Vasco'), with contrastive focus on 'América' (in response to the previous utterance 'Fluminense (a soccer team) has beaten Vasco'), in the bottom panel.

Multiple strategies are used in BP when the focus is early in the utterance. In early narrow focus cases, both falling and rising accents have been reported. Truckenbrodt et al. (2009) describe the presence of $\mathrm{H}+\mathrm{L}^{*}, \mathrm{~L}^{*} \mathrm{H}$ and $\mathrm{H}^{*}+\mathrm{L}$, with 
inter-speaker differences. In Fernandes (2007b), two main strategies are described $-\mathrm{H}^{*}+\mathrm{L}$ and $\mathrm{L}^{*}+\mathrm{H} \mathrm{L}-$, with inter- and intra-speaker variation. Similar findings are reported in Tenani \& Fernandes-Svartman (2008), also on the basis of data from the São Paulo variety. In early contrastive focus cases, several pitch accents have also been reported. Moraes (2008) describes two variants used in Rio de Janeiro that are differentiated by the presence of the peak on the prenuclear $\left(\mathrm{H}+\mathrm{L}^{*}\right)$ or the nuclear syllable $\left(\mathrm{H}^{*}+\mathrm{L}\right)$. The second variant is illustrated in Figure 4 (bottom panel). It can be argued that, at the pragmatic level, there is, in the Rio de Janeiro variety, a difference in meaning between these two variants, with the prenuclear peak correlating with a "colder" or "professorial" correction effect, while the peak in the stressed syllable signals a greater involvement of the speaker.

By and large, unlike in EP, in BP pitch accent type is not a robust strategy to signal focus. BP uses the EP focus accent $\mathrm{H}^{*}+\mathrm{L}$, together with the neutral declarative accent $\mathrm{H}+\mathrm{L}^{*}$ and with rising accents. In addition, expanded pitch range of $\mathrm{H}^{+} \mathrm{L}^{*}$ and the presence of a low tonal boundary marking the right edge the phonological phrase that contains the focused element have also been described. However, in BP as in EP, pitch range compression is a focus marker in statements with an early focus, yielding the reduction of the final pitch accent in postnuclear position (Fernandes 2007a,b; Truckenbrodt et al. 2009). Post-focal pitch range compression is illustrated in Figure 4 (bottom panel).

In summary, pitch accent placement and postfocal pitch range compression are the common prosodic strategies to signal focus in Portuguese. Besides these shared properties, EP consistently uses a special pitch accent type, whereas BP is characterized by the use of multiple prosodic strategies.

\subsection{Focus in questions}

Prosodic focus in questions has been less studied than prosodic focus in statements. In yes-no questions, a non-neutral form of interrogation may arise when some information is already shared by speaker and the listener, and the speaker challenges, doubts, or asks about the information that is shared. The piece of information that is challenged is the focus of the question. For example, in the yes-no question Os rapazes compraram lâminas? ('Did the boys buy slides?'), a focus on lâminas would express the meaning 'I would like to know if they have bought slides and not something different'.

In EP, the nuclear contour of yes-no questions with focus on a particular constituent shows a pitch accent different from the one found in neutral yes-no questions: in focused questions the nuclear syllable shows low-rising pitch, and not the nuclear fall of neutral yes-no questions ( $\mathrm{H}+\mathrm{L}^{*}$ - see section 4.2$)$. The nuclear accent of focused questions has been described as $\mathrm{L}^{*}+\mathrm{H}$, and this particular accent occurs on the focused element irrespective of its early or late position in the sentence. If the focus is final, a boundary fall follows; if the focus is early, a boundary rise marks the right-edge of the question (Frota 2002a, 2014). Figure 5 illustrates both a late and an early focus case. 

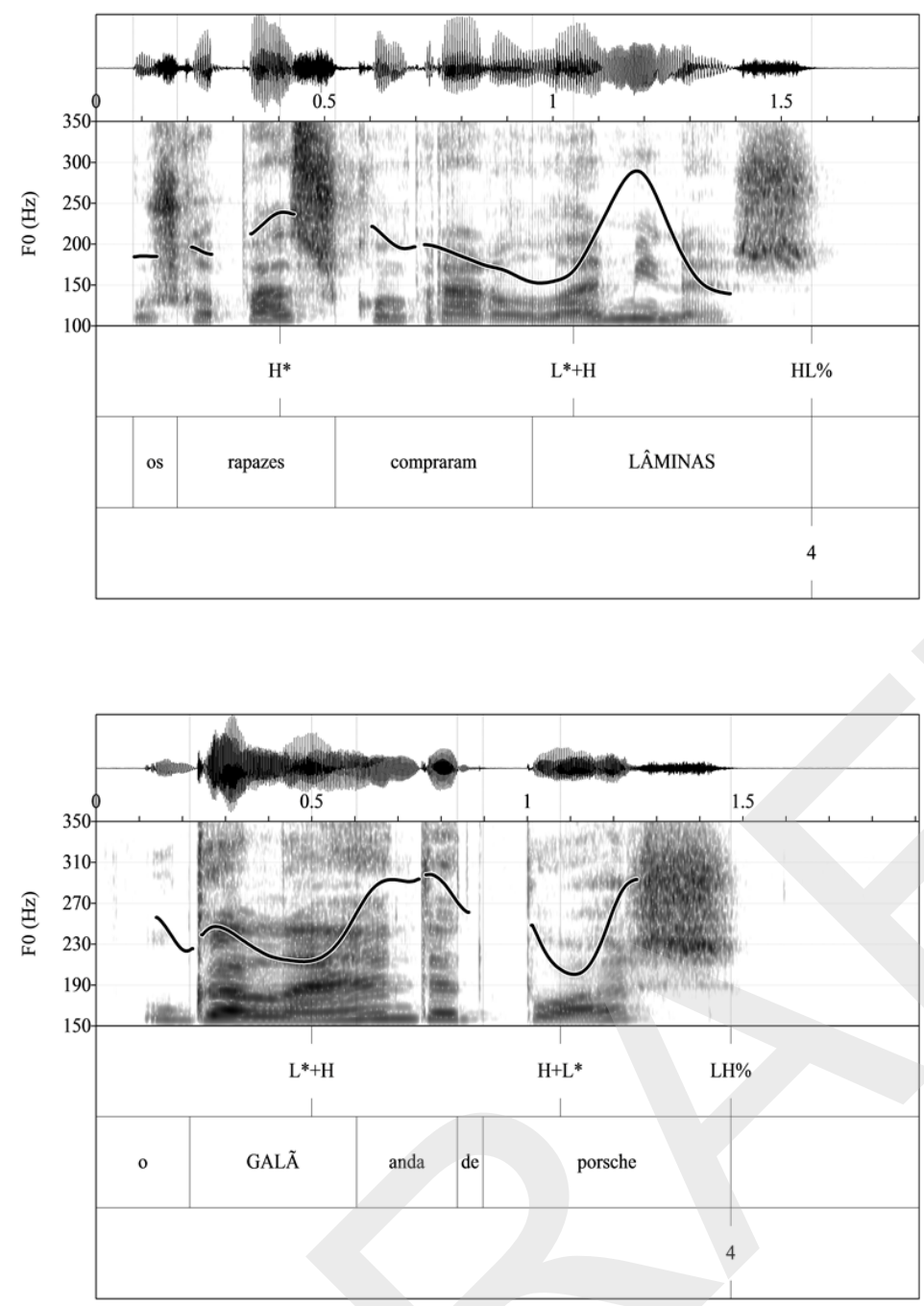

Figure 5. F0 contour of the focused yes-no question Os rapazes compraram lâminas? ('Did the boys buy slides'?), with the focus on 'lâminas', produced by an EP speaker (top panel); F0 contour of the focused yes-no question o galã anda de Porsche? ('Does the hero drive a Porsche?'), with the focus on galã, produced by an EP speaker.

Similarly to focus in statements, there is no deaccenting in the postnuclear contour in yes-no questions with an early focus, as shown in Figure 5B.

In $\mathrm{BP}$, and differently from EP, the same nuclear melody is found in neutral yes-no questions and yes-no questions with focus on a particular constituent: a LHL melody. Figure 6 shows examples of focused yes-no questions with a late and an early nucleus. Although there is a general agreement that the nuclear pitch accent is rising, different authors have proposed different analyses for the accentual rise, namely $\mathrm{L}+\mathrm{H}^{*}$ (Moraes 2008 for the Rio variety; Truckenbrodt et al. 2009 for the São Paulo variety) and L*+H (Crespo-Sandra et al. 2014) for several BP varieties. The different analyses, however, may result from differences in speech style, in additional pragmatic meanings, or in phonological interpretation of the data. The accentual rise is followed by a fall, analyzed as a L\% boundary. If the focus is early, the LHL occurs on the nuclear 
element and at the edge of the utterance (Figure 6, bottom panel). This suggests that the early nuclear rise is also followed by a low boundary tone, similarly to one of the possible strategies of prosodic marking of early focus in statements (see section 3.1). Finally, the presence of the LHL melody post-nuclearly indicates that, as in EP, there is no deaccenting in yes-no questions with an early focus.
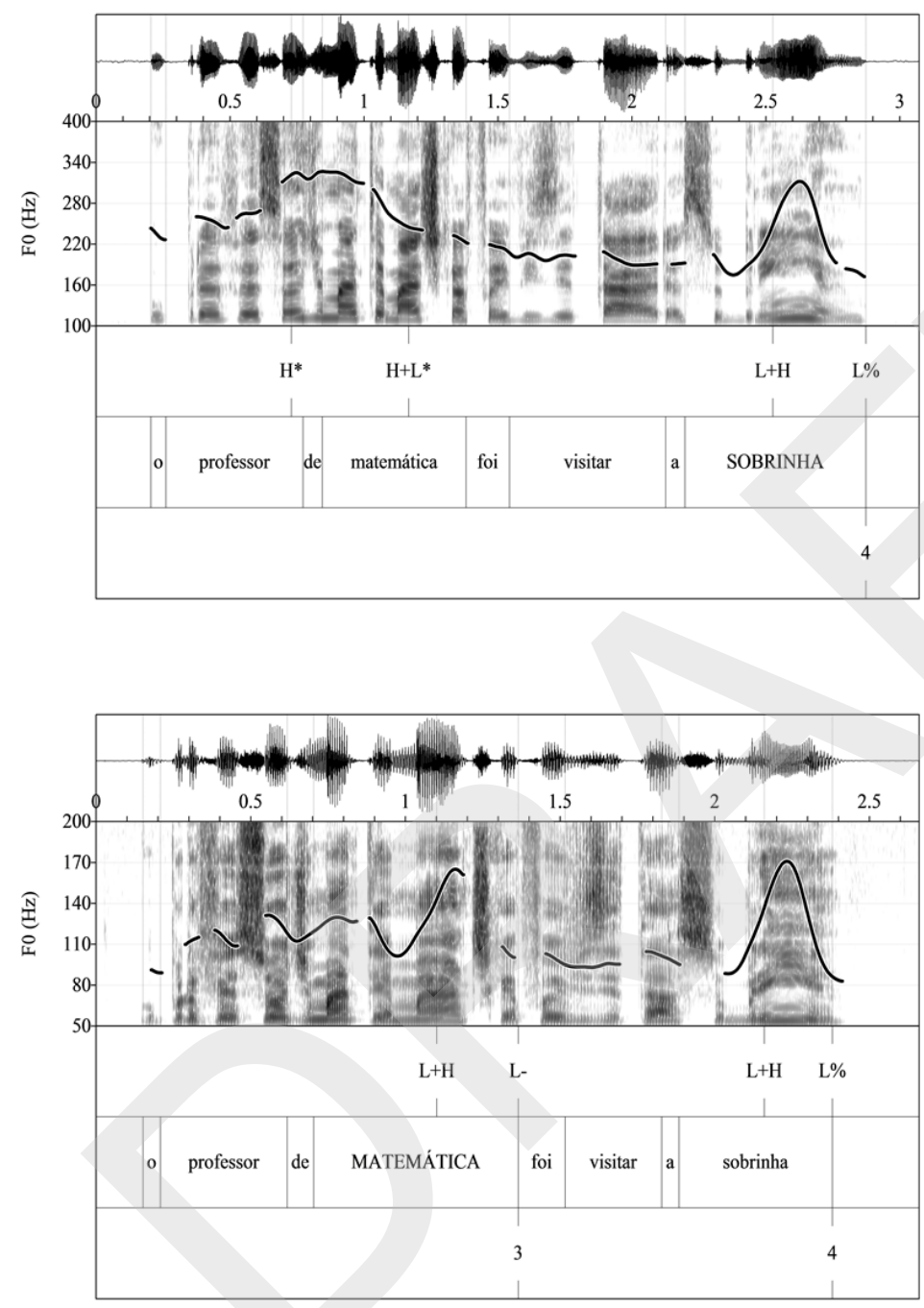

Figure 6. F0 contour of the focused yes-no question 0 professor de matemática foi visitar a sobrinha? ('Has the mathematics teacher visited her nephew?', produced by a BP speaker with the focus on 'sobrinha' (top panel), and with the focus on 'de matemática' (bottom panel).

Despite important differences in the melodies of focused yes-no questions, the two varieties of Portuguese employ accentual rises to signal focus and show no postnuclear deaccenting.

\section{Intonation and utterance types}


The distinction between utterance types is among the phrase-level meanings conveyed by intonation. Besides the demarcative function of chunking the speech stream into prosodic units and the culminative function of highlighting important information, the melody of speech can contrast paradigmatically to signal different sentence types. In Portuguese, these contrasts are usually achieved by means of the nuclear contour, that is the pitch accent associated to the nuclear syllable and any tonal events on subsequent post-tonic syllable(s). In this section, we describe the nuclear contours that characterize statements, questions (wh-questions and yes-no questions), imperatives (commands and requests), and vocatives (initial call and insistent call). Together with a basic intonational inventory of pitch accents and boundary tones, other key features of the intonation system of Portuguese are discussed, namely the ways the language explores tonal alignment to convey meaning distinctions and the preferred tune-text accommodation strategies when the segmental string, by virtue of not being long enough, imposes pressure on the realization of the tune.

\subsection{Statements}

In Portuguese, broad focus or neutral statements are characterized by a final fall through the stressed syllable of the nuclear word, which is represented by an accentual low target immediately preceded by a peak $\left(\mathrm{H}+\mathrm{L}^{*}\right)$. The accentual fall is followed by low pitch at the bottom of the speaker's range, or in other words by a low boundary tone ( $\mathrm{L} \%)$. The tune $\mathrm{H}+\mathrm{L} * \mathrm{~L} \%$ is thus the nuclear contour of declarative intonation in Portuguese, as illustrated in Figure 7 (and also in Figures 1 and 2 above).

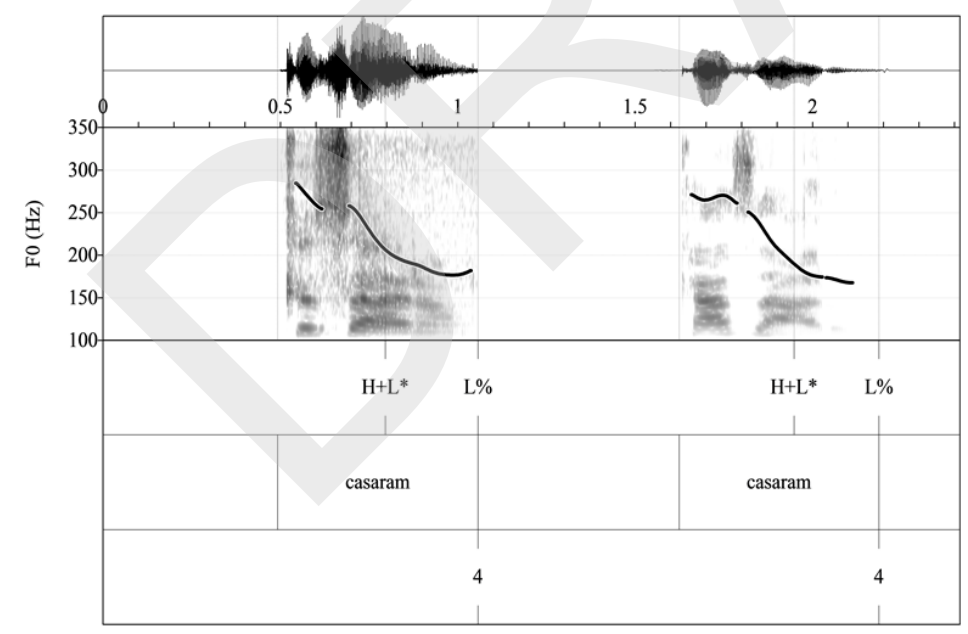

Figure 7. F0 contour of the neutral statement Casaram ('(They got) married, as in an answer to What about John and Mary?), produced by an EP speaker (left) and a BP speaker (right).

If the nuclear contour does not distinguish between European and Brazilian Portuguese declarative intonation, the prenuclear stretch sets the two varieties of Portuguese apart. The difference is clearly seen in longer utterances, and is due to the sparse pitch accentuation that characterizes EP versus the rich 
pitch accentuation that characterizes BP already described in section 2 above. In EP, as shown in Figure 1, the prenuclear contour contains an initial high tone and an accentless stretch up to the nuclear fall. In BP, by contrast, the prenuclear contour shows a pitch accent per prosodic word. Non-final stressed syllables typically exhibit a rising melody, that has been described either as a $\mathrm{L}^{*}+\mathrm{H}$ or a $\mathrm{L}+\mathrm{H}^{*}$ accent (Tenani 2002; Fernandes 2007a,b; Moraes 2008). Considering the variability in melodic shape of the pre-nuclear stressed syllables, across and within speakers of the same variety (at least for Rio de Janeiro and São Paulo), it seems more adequate in the present stage to leave the rising pitch accent unspecified as to the starred tone $(\mathrm{L}+\mathrm{H})$. Further research is needed to clarify the format of the prenuclear rising accent in BP. Importantly, BP conforms to the generalization that languages with a dense pitch accent distribution tend to show the same type of prenuclear pitch accent (as suggested in Jun 2005). Another feature that distinguishes between BP and EP is the presence of accentual-like tonal events in pre-tonic syllables in BP. These tonal events, usually in the form of high or rising pitch, have been described in statements (whether neutral or focalized) and other sentence types (Frota \& Vigário 2000; Tenani 2002; Moraes 2003; Vigário \& Fernandes-Svartman 2010; Frota et al., in press). The number of syllables to the left of the stressed syllable and the presence of secondary stress are among the conditions that may govern the distribution of such accentual tones, but further research is required.

\subsection{Questions}

In this section, the intonation of two major types of questions is described: whquestions and yes-no questions, as types of pragmatically neutral informationseeking questions. In Portuguese, wh-questions are syntactically and lexically marked. The presence of a question word identifies the utterance as a question. Question words typically appear at the beginning of the sentence (although whquestions with in situ wh-words are also possible). Here we will only be concerned with the intonation of wh-questions with the question word in sentence initial position. Unlike wh-questions, yes-no questions have the same surface syntactic properties as declarative sentences and contain no lexical marker. Thus Portuguese is one among the large group of languages that signals that distinction between statements and yes-no questions only by prosodic means.

\subsubsection{Wh-questions}

Descriptions of wh-question intonation have pointed to similarities between whquestions and statements. In Portuguese, both sentence types show the nuclear contour $\mathrm{H}+\mathrm{L}^{*} \mathrm{~L} \%$. In the case of European Portuguese, the prenuclear contour shows a high plateau similar to that found in statements, as illustrated in Figure 8A. The presence of a higher initial pitch in questions relative to statements seems to be an optional feature. Another optional feature is the presence of a final rise after the nuclear pitch accent $\mathrm{H}+\mathrm{L}^{*}$, which seems to add additional politeness to the question (Frota 2002a, 2014). In Brazilian Portuguese, unlike in European Portuguese, the prenuclear contour seems to distinguish wh-questions from statements: wh-questions are characterized by an extra-high pitch in the 
wh-word and a gradual fall over the following syllables, until the last stressed syllable, as shown in Figure 8B. This prenuclear accent contrasts with the default rising accent found in statements, and has been represented as $\mathrm{H}+\mathrm{H}^{*}$ (Moraes 2008).
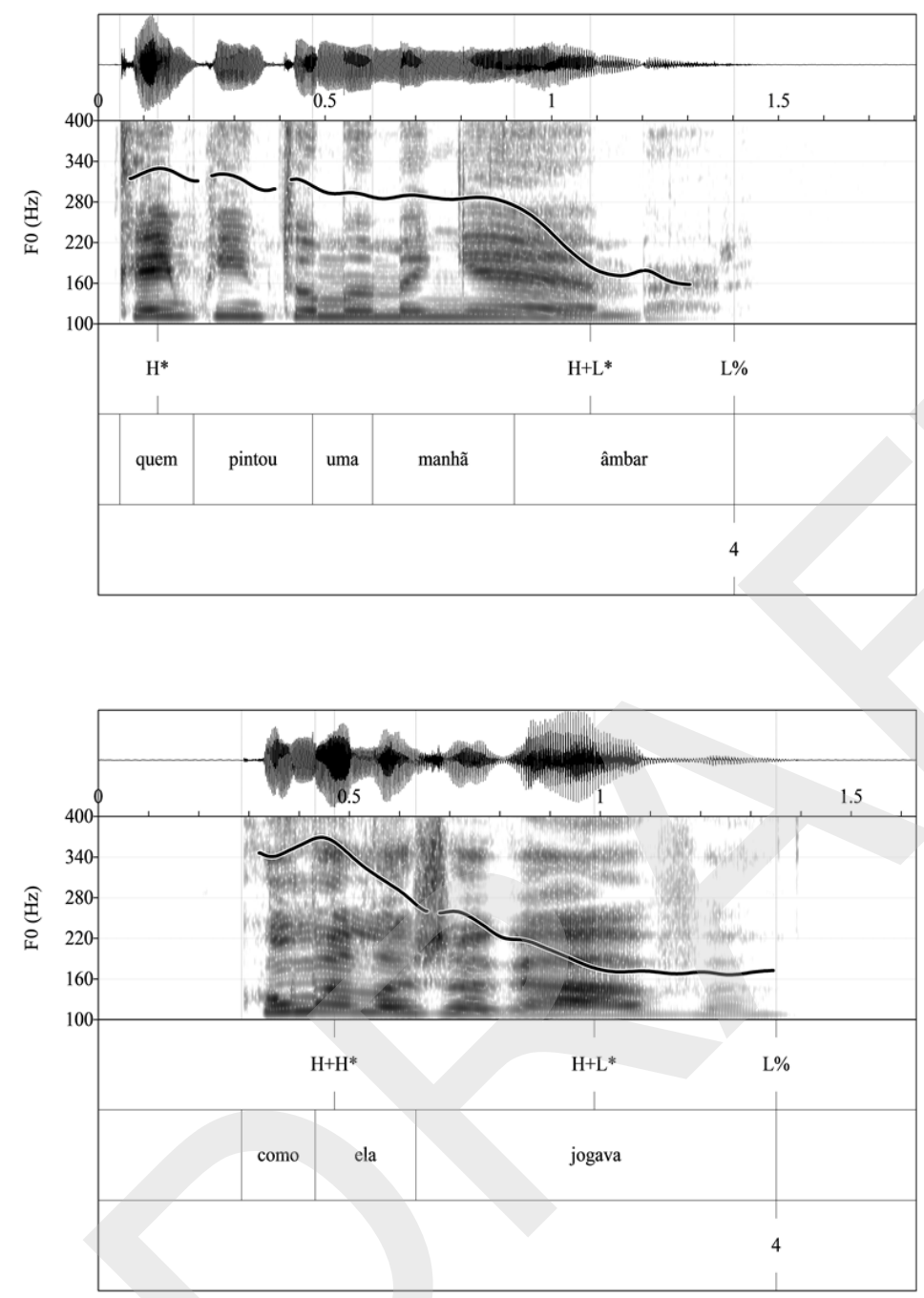

Figure 8. Top panel: F0 contour of the wh-question Quem pintou uma manhã âmbar? ('Who painted an amber morning?'), in EP; Bottom panel: F0 contour of the wh-question Como ela jogava? ('How did she (used to) play?'), in BP.

Given the high beginning of wh-questions in BP and the following gradual fall, the pitch level in the nuclear accent is usually lower than in statements. However, perceptual tests with resynthesized stimuli in which the nuclear pitch contour of the statement was replaced by that of the wh-question and vice-versa showed that this phonetic difference is not perceptually relevant for sentence type identification (Moraes 2008).

\subsubsection{Yes-no questions}


Contrary to wh-questions, the nuclear contour clearly distinguishes yes-no questions from statements in Portuguese. Besides this common feature, the distinction is conveyed differently in EP and BP: in EP, interrogation is signaled by the boundary tone; in $\mathrm{BP}$, it is conveyed by a pitch accent contrast. Illustrative examples of neutral yes-no questions are provided in Figure 9.
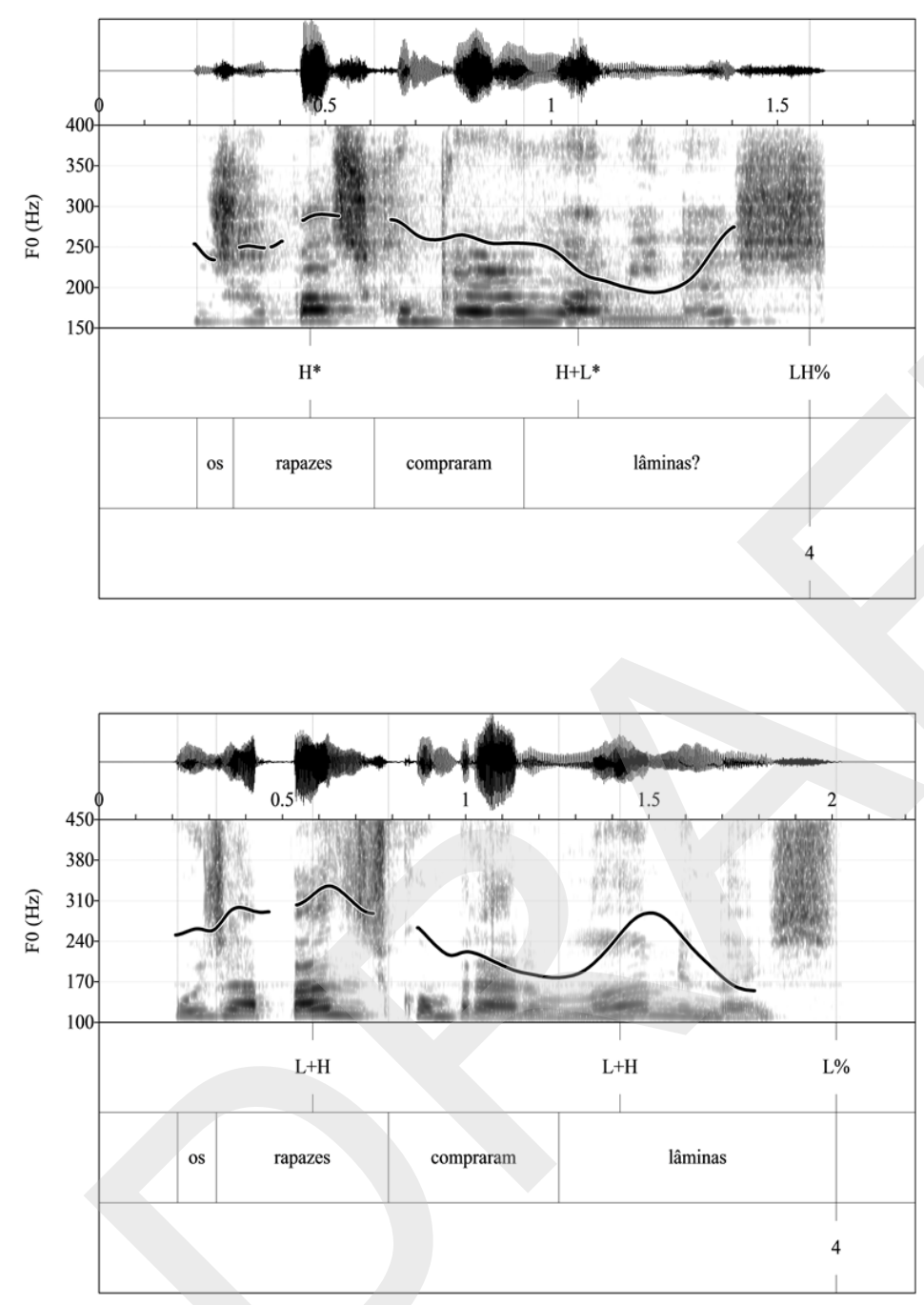

Figure 9. F0 contour of the yes-no question Os rapazes compraram lâminas? ('Did the boys buy slides?'), produced by an EP speaker (top panel) and a BP speaker (bottom panel).

In EP, yes-no questions show an obligatory final rise as the distinctive feature that sets them apart from statement and wh-question intonation (Frota $2002,2014)$. The properties of the final fall-rise of the yes-no question tune show that it consists of an accentual fall $\left(\mathrm{H}+\mathrm{L}^{*}\right)$ and a boundary rise $(\mathrm{LH} \%)$, as exemplified in Figure 9A. In BP, by contrast, the distinctive feature is the nuclear accent, which shows a rise through the final stressed syllable with a late alignment of the F0 peak (Moraes 2006b, 2008). In BP yes-no questions end with a rise-fall contour that comprises an accentual rise $(\mathrm{L}+\mathrm{H})$ and a $\mathrm{L} \%$ boundary (Figure 9B). The accentual rise as been analysed both as a $\mathrm{L}+\mathrm{H}^{*}$ accent (Moraes 
\& Colamarco 2007; Moraes 2008) or a $\mathrm{L}^{*}+\mathrm{H}$ accent (Frota et al. in press, CrespoSandra et al. 2014). The two varieties of Portuguese thus explore different intonational markers to signal interrogation.

Yes-no question intonation provides a fruitful ground to examine tunetext accommodation strategies in Portuguese. Given the complex fall-rise (EP) or rise-fall (BP) nuclear contours, in an utterance that ends in a word with final stress the segmental string has only one syllable available for the realization of the complex tune. Languages are usually divided into compression languages, i.e., those that compress the tune to fit the segmental string, and truncation languages, i.e., those that truncate the tune to fit the segmental string (Ladd 2008). In EP, the fall-rise contour is fully realized due to the extension of the segmental string to cope with tonal realization (Frota 2000, 2014). This is achieved by extended lengthening of the nuclear vowel or by insertion of an epenthetic vowel, as in Figure 10 (top panel). Therefore, EP is neither a compression nor a truncation language.
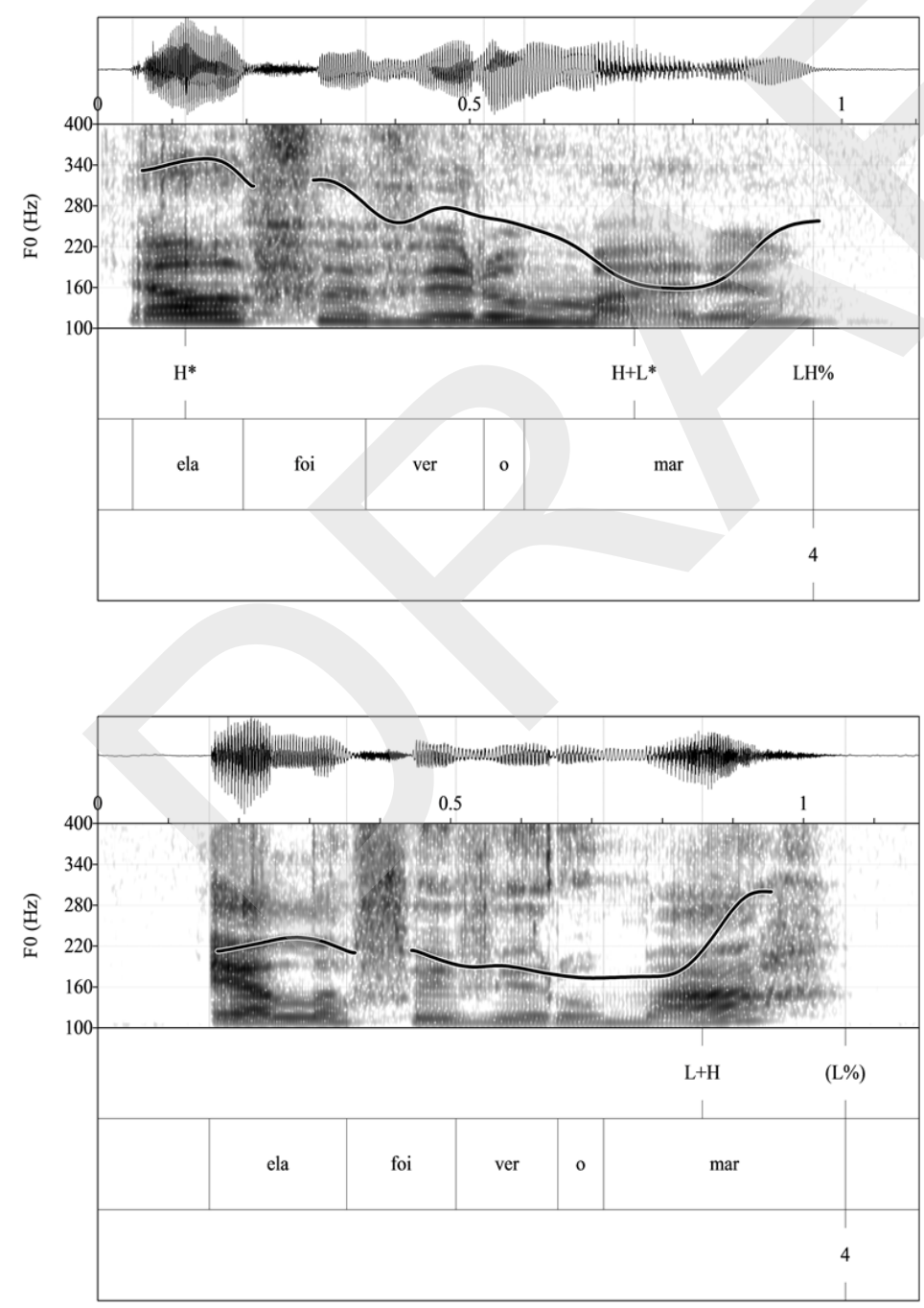

Figure 10

F0 contour of the yes-no question Ela foi ver o mar? ('Has she gone to see the sea?'), produced by an EP speaker (top panel), and a BP speaker (bottom panel). 
BP seems to show tune-text accommodation strategies different from EP, allowing truncation of the low boundary tone (Moraes \& Colamarco 2008; Silva \& Frota 2014), as illustrated in Figure 10 (bottom panel). In yes-no questions in $\mathrm{BP}$, unlike in EP, it is the tune that gets accommodated to the text.

\subsection{Imperatives}

In Portuguese, as in most (if not all) Romance languages, imperative sentences are characterized by morphosyntactic markers that distinguish them from statements (namely, verb initial position, use of the $2^{\text {nd }}$ person and imperative mood). In this section, the intonation of imperative sentences that convey commands and requests is described.

\subsubsection{Commands}

The intonation of commands exhibits different features in EP and BP. In EP, commands typically show the nuclear accent of narrow focus declaratives (whether the nucleus is on the verb or on the object) or of focalized yes-no questions (if the nucleus is on the verb), followed by a low boundary tone. In other words, commands are characterized by the use of focus accents $\left(\mathrm{H}^{*}+\mathrm{L}\right.$ or $\mathrm{L}^{*}+\mathrm{H}$ ), but crucially not of the $\mathrm{H}+\mathrm{L}^{*}$ nuclear accent found in neutral statements (Frota 2014). Differently, in BP the nuclear configuration of commands is the same of neutral statements, that is $\mathrm{H}+\mathrm{L}^{*} \mathrm{~L} \%$ (Moraes 2008). The typical EP and BP patterns are illustrated in Figure 11. Given that the most frequent nuclear configurations for commands in Romance languages are either the broad focus or the narrow focus statements contours (Frota \& Prieto, in press), BP and EP respectively exemplify these two common trends. In the prenuclear stretch, commands are characterized by a high tone on the first stressed syllable of the utterance.

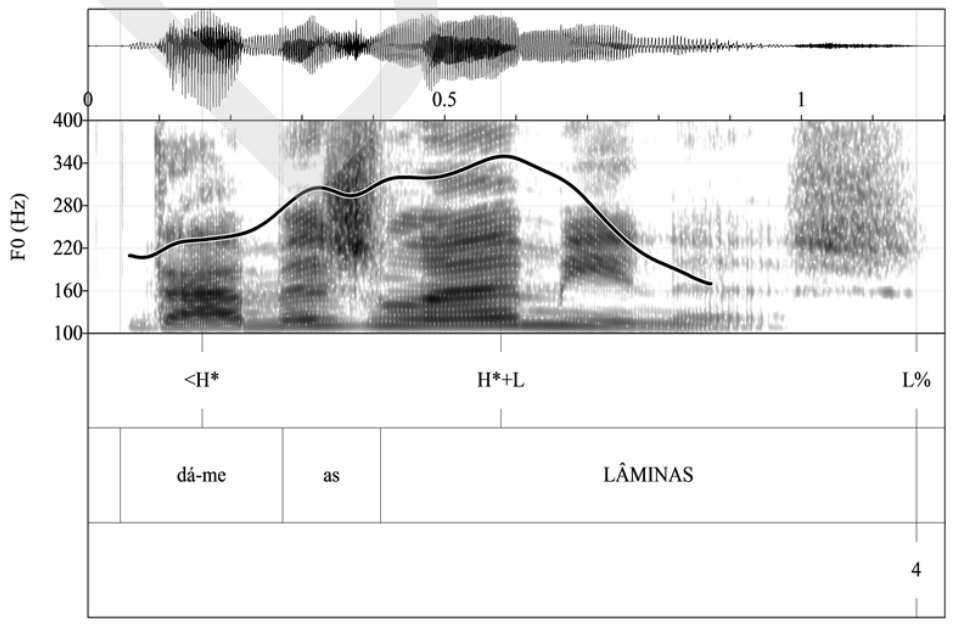




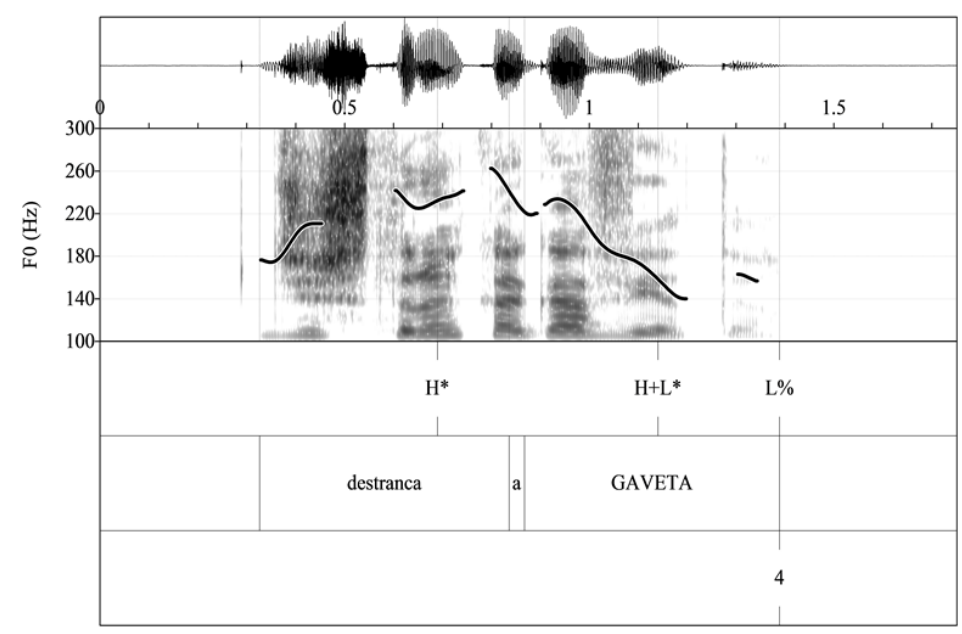

Figure 11.Top panel: F0 contour of the utterance Dá-me as lâminas ('Give me the slides'), produced as a command by an EP speaker; Bottom panel: F0 contour of the utterance Destranca a gaveta ('Unlock the drawer'), produced as a command by a BP speaker.

The intonational properties of commands in Portuguese seem not distinguish this sentence-type from statements or wh-questions (some phonetic traits like peak height could act as possible clues, but their consistency and efficacy has not been demonstrated). It is the combination of the particular morphosyntax of these utterances with the intonational features just described that may unambiguously signal the utterance as a command.

\subsubsection{Requests}

Like in commands, European and Brazilian Portuguese also display different intonational patterns in imperative sentences expressing requests. In EP, the presence of a low nuclear contour $\left(\mathrm{L}^{*} \mathrm{~L} \%\right)$ characterizes a request, contrasting sharply with the falling (or rising, in the case of an early nucleus) pattern found in commands. The prenuclear contour shows an initial high tone on the first stressed syllable or at the left-edge of the utterance if no stressed syllable is available (cf. Frota 2014). An example of the intonation contour of requests in EP is provided in Figure 12 (top panel).

In $\mathrm{BP}$, requests show a rise-fall nuclear configuration that has been analyzed as $\mathrm{L}+\mathrm{H}^{*} \mathrm{~L} \%$ (Moraes 2008; Moraes \& Colamarco 2008). This circumflex contour, illustrated in Figure 12 (bottom panel), contrasts with the nuclear fall $\left(\mathrm{H}+\mathrm{L}^{*} \mathrm{~L} \%\right)$ found in commands. The first stressed syllable displays a prenuclear accentual peak that is usually realized with particularly high pitch. 

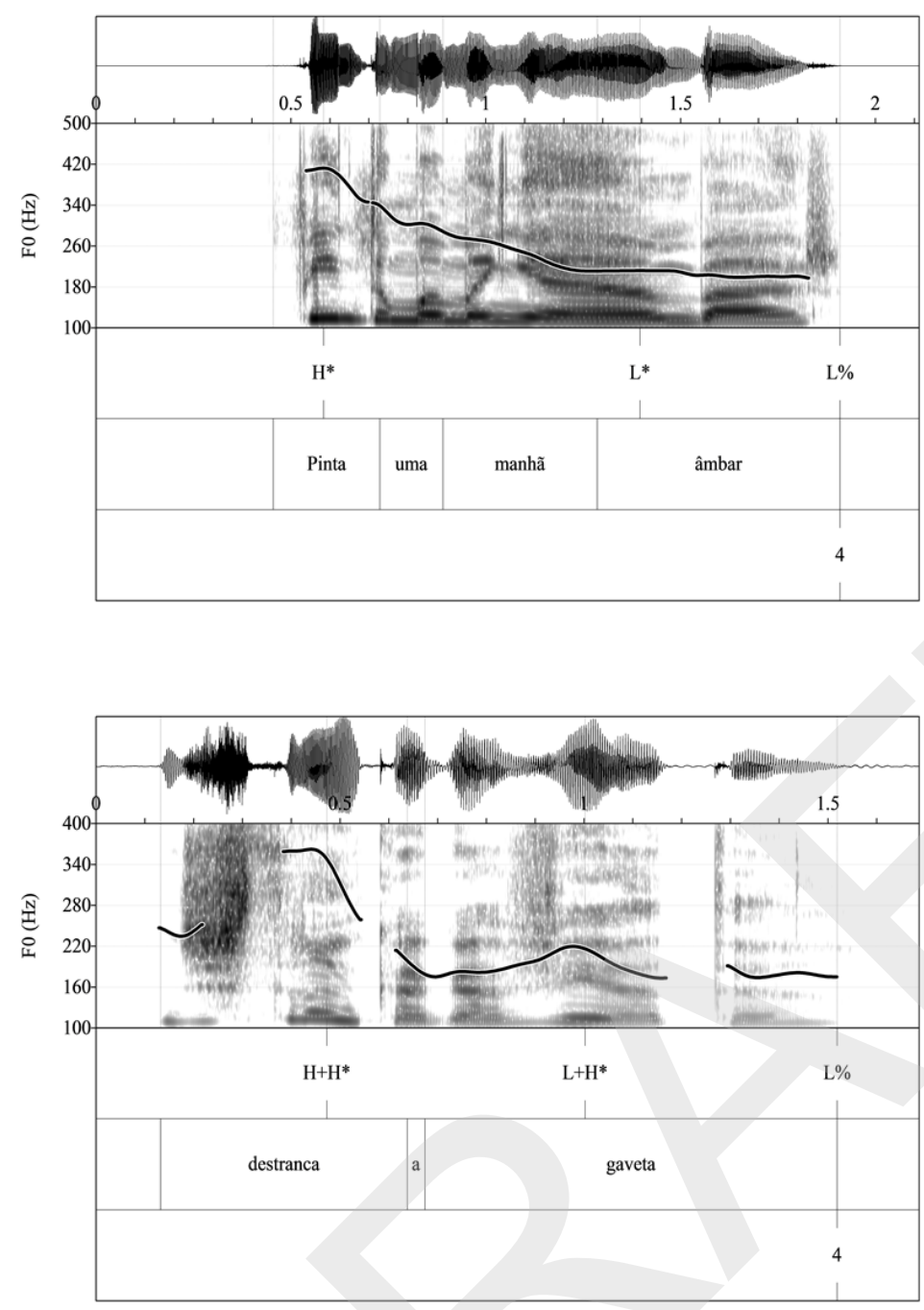

Figure 12. Top panel: F0 contour of the utterance Pinta uma manhã âmbar ('Paint an amber morning'), produced as a request by an EP speaker; Bottom panel: F0 contour of the utterance Destranca a gaveta ('Unlock the drawer'), produced as a request by a BP speaker.

The distinction between commands and requests in Portuguese is thus mainly conveyed by the nuclear pitch accent (falling vs. low nucleus in EP; falling vs. rising nucleus in BP). Another trait that is common to EP and BP is the lengthening of the nuclear syllable in the request contour. Importantly, perception experiments have shown that native EP and BP speakers are able to reliably identify commands and requests on the basis of their prosody (Frota 2014; Morais \& Rilliard 2014).

\subsection{Vocatives}

Like in many European languages, calling contours in Portuguese show two main variants: the vocative chant or sustained pitch variant and the low call variant (Ladd 2008; Moraes \& Silva 2011; Frota 2014; Frota \& Prieto, in press). 
Interestingly, however, EP and BP use different variants of the calling contour to express similar pragmatic meanings.

\subsubsection{Vocative chant}

The typical vocative chant, that is characterized by high pitch on the nuclear syllable followed by a step down into the first post-nuclear syllable after which the pitch level is sustained, is illustrated in Figure 13. This contour has been analyzed as consisting of a $\mathrm{L}+\mathrm{H}^{*} ! \mathrm{H} \%$ melody, where the leading tone may show variable realization (Frota 2014; Frota et al., in press). The chanted melody is accompanied by a characteristic duration pattern whereby the nuclear syllable and especially the final syllable are lengthened.

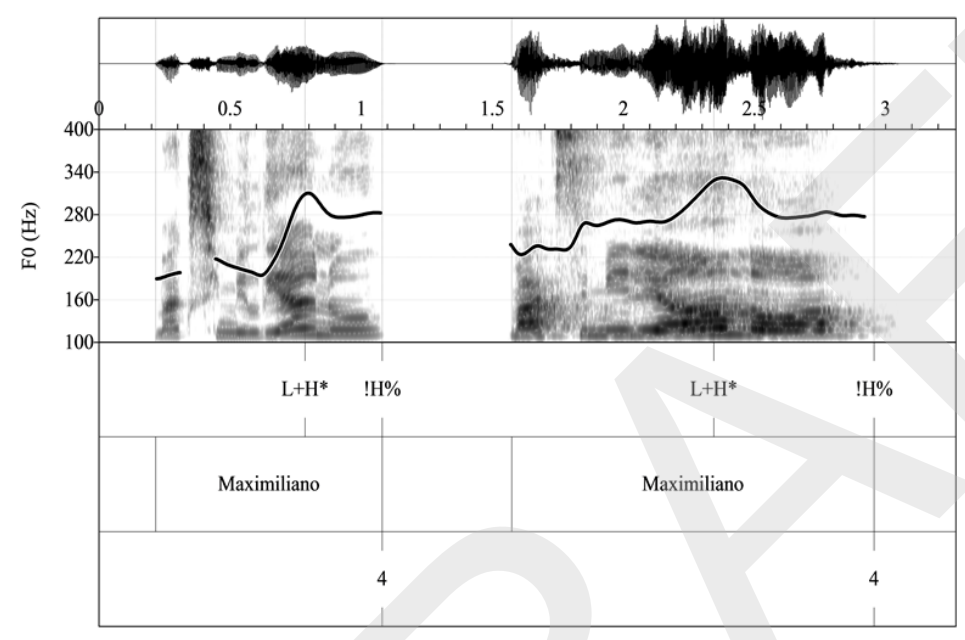

Figure 13. F0 contour of the utterance Maximiliano ('Maximiliano') produced by an EP speaker (left) and a BP speaker (right), illustrating the vocative chant.

The prosodic features of the vocative chant block vowel reduction patterns that otherwise are present in the language. In EP, post-tonic phonetic vowel reduction (or even vowel deletion, as in the case of a word-final [u]) is blocked and thus the final unstressed vowel is fully realized, as shown in Figure 13 (see also Frota 2014). In BP, post-tonic final mid vowels are realized as high vowels. This change in vowel quality is blocked in the vocative chant, and the final vowel is realized as a mid vowel (i.e., [o] does not become [u], as shown in Figure 13). Furthermore, to comply with both the chanted melody and the lengthening requirements, the nuclear syllable gets split up when there is no

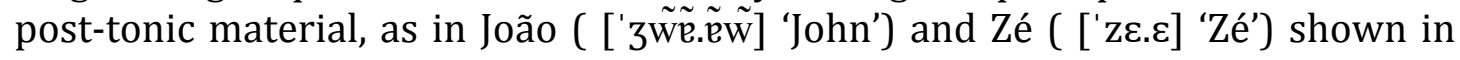
Figure 14. 


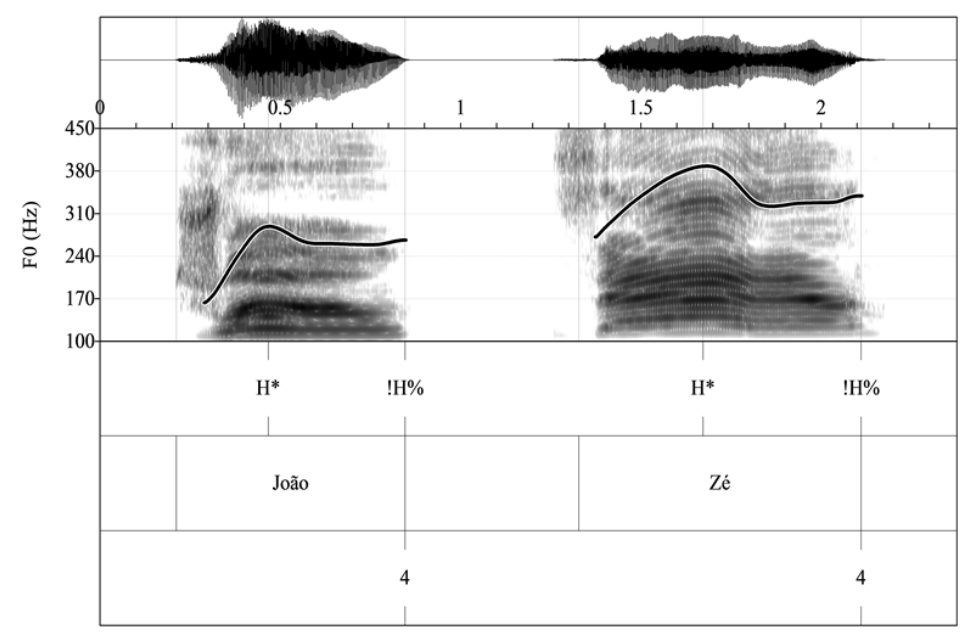

Figure 14. The calling contours João ('John'), produced by an EP speaker (left), and Zé ('Zé'), produced by a BP speaker (right), illustrating the vocative chant.

It can thus be concluded that the vocative chant contour is part of intonation system of Portuguese and is realized with very similar properties in $\mathrm{EP}$ and BP. However, the most common pragmatic uses of this calling contour seem to distinguish between EP and BP. In European Portuguese, the vocative chant is the calling contour that is typically used in the context of a greeting call or an initial call. In Brazilian Portuguese, by contrast, the vocative chant tends to be used in the context of an insistent call or when the person called is far away and not paying attention. Overall, this pattern in BP is rare and felt as more marked (at least, in the Rio de Janeiro variety). The most common calling contour in BP is the low call.

\subsubsection{Low call}

The low call pattern is characterized by a nuclear rise immediately followed by falling pitch, as shown in Figure 15. The difference between the low call and the vocative chant lies on the boundary tone, and thus the low call melody is analyzed as $\mathrm{L}+\mathrm{H}^{*} \mathrm{~L} \%$, again with variable realization of the leading low tone (e.g., Frota 2014, Frota et al., in press). Furthermore, unlike in the vocative chant, in the low call the boundary syllable is not lengthened, the reduction of the final vowel is not blocked (Figure 15, top panel), and there is no split up of the nuclear syllable in the absence of post-tonic material (Figure 15, bottom panel). 

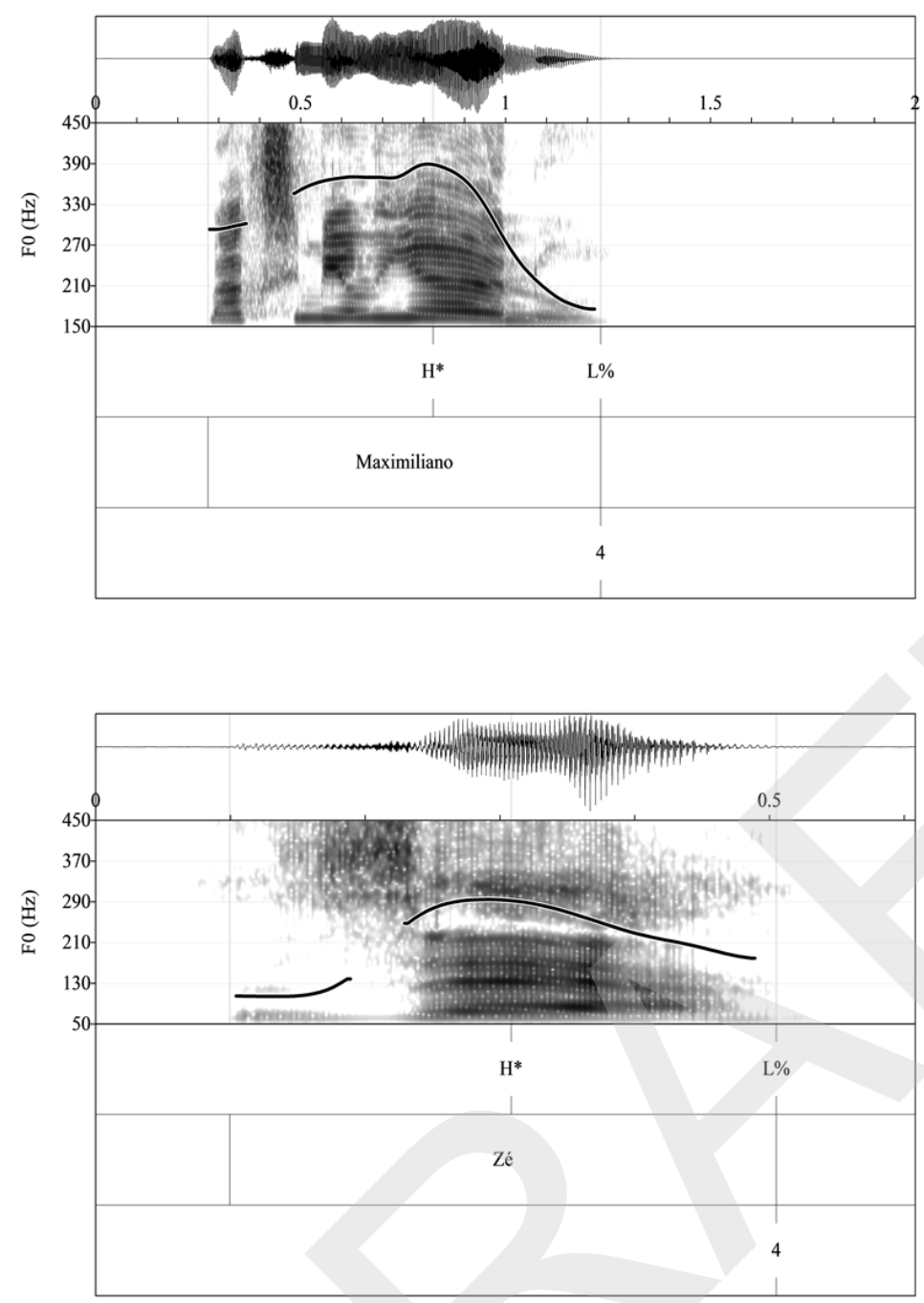

Figure 15. The calling contours Maximiliano ('Maximiliano'), produced by an EP speaker (top panel), and Zé ('Zé'), produced by a BP speaker (bottom panel), illustrating the low call.

Although the formal properties of the low call are strikingly similar in EP and BP, the functional use of this contour differs: in EP, the low call conveys an insistent and impatient call; in BP, it is the most frequent calling contour and is commonly used either as a greeting call or an insistent call (with wider pitch range and higher intensity in the latter case).

\section{Intonation across varieties of Portuguese}

Studies of intonational variation within Portuguese, using a comparable and theoretically informed framework of analysis, are recent developments in the field of the intonational phonology of Portuguese (Vigário \& Frota 2003; Frota \& Vigário 2007; Fernandes 2007b; Vigário \& Fernandes-Svartman 2010; Cruz \& Frota 2011, 2012, 2013; Cruz 2013; Silva \& Frota 2014; Crespo-Sandra et al. 2014; Frota et al., in press). 
A systematic comparison between varieties of European Portuguese and varieties of Brazilian Portuguese was conducted in Frota et al. (in press). Three main dimensions of variation were highlighted: the inventory of nuclear contours, intonational phrasing and pitch accent distribution. Variation in the intonational inventory revealed important systemic and semantic differences across varieties. For example, yes-no questions, as described in section 4.2 above, have different contours in the Lisbon variety of European Portuguese and the Rio de Janeiro variety of Brazilian Portuguese, the two varieties on which the present chapter is based. Furthermore, the contour of yes-no questions may also differ across varieties of EP (with southern varieties showing a all-rising configuration instead of the fall-rise found in the Lisbon variety) and across varieties of BP (with northern varieties showing a high tonal boundary that contrasts with the low boundary found in Rio de Janeiro and other centralsouthern varieties). Variation is not only achieved through the presence and/or use of different contours across varieties. It is also the case that the same contour may be used with different meanings. A prominent example of this sort of difference are the meanings expressed by the two variants of the calling contours, described in section 4.4

A second dimension of variation concerns intonational phrasing. As noted in section 3, in BP a low tonal boundary may mark the right edge of a prosodic domain smaller than the intonational phrase in utterances with an early focus, whereas in EP only the intonational phrase shows tonal boundary marking.

The third dimension of variation results from the ways pitch accents are distributed within utterances. Besides the contrast between the sparse pitch accentuation that characterizes the Lisbon variety of EP and the rich pitch accentuation that characterizes the Rio de Janeiro variety of BP (described in section 2), within EP and BP the distribution of tonal events may also differ. Within BP, southern varieties tend to show a denser distribution of tonal events. Within EP, it is the standard (Lisbon) variety that shows a sparser distribution than other EP varieties.

Alongside the variation, a basic set of properties that characterize the intonational system of Portuguese were identified in Frota et al. (in press): rightheaded prosodic phrases, absence of postnuclear deaccenting (see also section 3 above), and two main types of tonal events, namely pitch accents and boundary tones, with the prevalence of bitonal accents and simple boundaries.

\section{Portuguese Intonation within Romance}

A typological look at the intonation of Portuguese within the Romance space concludes this chapter. In Portuguese, as in Romance languages in general, forms of grammaticalization of the three main functions of intonation are found: demarcation or phrasing, highlighting or prominence, and signaling different utterance types.

Portuguese is similar to most Romance languages in showing intonationally-defined constituents that are highly ranked in prosodic structure, namely the intonational phrase (the exceptions are French and Occitan, which make also use of a lower level unit in their phrasing patterns, the accentual phrase - cf. Frota \& Prieto, in press). However, as described in section 2, 
Brazilian and European Portuguese (the standard variety) crucially differ in the domain for the distribution of pitch events: BP is like most other Romance languages in having a low domain for pitch accentuation (in BP nearly every prosodic word gets a pitch accent), whereas the standard variety of EP is an exception within Romance languages with the intonational phrase as the domain for pitch accent distribution. Consequently, in BP as in most Romance languages, but unlike in EP, the prenuclear contour shows a dense distribution of pitch events that consists of a regular alternating tonal pattern (Jun 2014; Frota \& Prieto, in press). In EP, by contrast, tonal events occur essentially at the edges of intonational phrases, which underscores their demarcative function.

In most Romance languages, nuclear prominence is rightmost and Portuguese is no exception to this general pattern. Portuguese, though, is a language that uses intonation as a device to highlight important information, together with syntactic or morphological means (see section 3). Thus, changes in the placement of the nuclear accent, pitch accent type, extended pitch range in the focal element, and post-focal pitch range compression can be used as means to express focus in Portuguese (perhaps in a stronger and more flexible way in EP than in BP), like in some Romance languages or West Germanic languages. Intonational marking of sentence types and pragmatic meanings is commonly achieved by the use of different nuclear configurations in Romance languages (Frota \& Prieto, in press). In Portuguese, this role is mainly taken by pitch accent contrasts, since both EP and BP make a more restricted use of contrastive tonal boundaries, when compared to languages like Catalan, Spanish, or Italian (Moraes 2008; Frota et al., in press). Like in most Romance languages, in Portuguese bitonal pitch accents are more productive in nuclear configurations than monotonal accents.

On the one hand, it can be concluded that the intonation system of Portuguese exhibits the main features that characterize the intonation of Romance languages. On the other hand, it seems clear that Brazilian Portuguese intonation is more typically Romance-like than (Standard) European Portuguese intonation.

\section{Acknowledgements}

We are grateful to the research team of the InAPoP project, for preparing the figures in this chapter. A set of the examples presented here were selected from the InAPoP speech database. The preparation of this chapter was partially funded by the grant PTDC/CLE-LIN/119787/2010 (FCT/MEC, Portugal), awarded to the first author.

\section{(7194 words) (w/references 8.656 words)}

\section{References}

Barbosa, P. (2012) Conhecendo melhor a prosódia: aspectos teóricos e metodológicos daquilo que molda nossa enunciação. Revista de Estudos da Linguagem 20 (1): 11-27.

Crespo-Sendra, V., M. Cruz, J. Silva and S. Frota (2014). Asking questions across Portuguese varieties. Talk given at The 6th International Conference on Tone and 
Intonation in Europe. Netherlands: University of Utrecht (http://ww3.fl.ul.pt/LaboratorioFonetica/files/Crespo-Sendraetal_TIE6.pdf).

Cruz-Ferreira, M. (1998). 'Intonation in European Portuguese', in D. Hirst and A. Di Cristo (eds.), Intonation Systems. A Survey of Twenty Languages. Cambridge: Cambridge University Press, 167-178.

Cruz, Marisa (2013). Prosodic variation in EP: phrasing, intonation and rhythm in central-southern varieties. PhD Dissertation, Universidade de Lisboa.

Cruz, Marisa, and Frota, Sónia (2011). 'Prosódia dos tipos frásicos em variedades do Português Europeu: produção e percepção', in A. Costa, I. Falé, and P. Barbosa (eds.), Textos Seleccionados - XXVI Encontro Nacional da Associação Portuguesa de Linguística. Porto: Associação Portuguesa de Linguística, 208-225.

Cruz, Marisa, and Frota, Sónia (2012). 'Para a prosódia do foco em variedades do Português Europeu', in A. Costa, C. Flores, and N. Alexandre (eds.), Textos Selecionados - XXVII Encontro Nacional da Associação Portuguesa de Linguística. Lisboa: Associação Portuguesa de Linguística, 196-216.

Cruz, Marisa, and Frota, Sónia (2013). 'On the relation between intonational phrasing and pitch accent distribution. Evidence from European Portuguese varieties'. Proceedings of the $14^{\text {th }}$ Annual Conference of the International Speech Communication Association (ISCA) - Interspeech 2013, 300-304.

Elordieta, Gorka; Frota, Sónia, and Vigário, Marina (2005). 'Subjects, objects and intonational phrasing in Spanish and Portuguese', Studia Linguistica 59 (2/3), 110-143.

Fernandes, Flaviane (2007a). 'Tonal association in neutral and subject-narrowfocus sentences of Brazilian Portuguese: a comparison with European Portuguese', Journal of Portuguese Linguistics 5/6 (Special Issue on the Prosody in Ibero-Romance and related languages, ed. by G. Elordieta and M. Vigário), 91115.

Fernandes, Flaviane (2007b). Ordem, focalização e preenchimento em Português: sintaxe e prosódia. PhD dissertation, State University of Campinas, Brazil.

Frota, S. (1997). 'Association, Alignment, and Meaning: the tonal sequence HL and Focus in European Portuguese', in A. Botinis, G. Kouroupetroglou and G. Carayiannis (eds.), Intonation: Theory, Models and Applications-Proceedings of an ESCA Workshop. Athens: ESCA/University of Athens, 127-130.

Frota, S. and P. Prieto. (in press). Intonation in Romance: systemic similarities and differences. In S. Frota \& P. Prieto (eds.). (in press). Intonation in Romance. Oxford: Oxford University Press.

Frota, S., D'Imperio, M., Elordieta, G., Prieto, P. and Vigário, M. (2007), 'The phonetics and phonology of intonational phrasing in Romance', in P. Prieto, J. 
Mascaró \& M.-J. Solé (eds.) Prosodic and Segmental Issues in (Romance) Phonology. Amsterdam/Philadelphia: John Benjamins, 131-153.

Frota, S., M. Cruz, F. Fernandes-Svartman, M. Vigário, G. Collischonn, A. Fonseca, C. Serra \& P. Oliveira (in press). Intonational variation in Portuguese: European and Brazilian varieties. In Sónia Frota \& Pilar Prieto (eds). Intonation in Romance. Oxford: Oxford University Press.

Frota, Sónia (2000). Prosody and focus in European Portuguese. Phonological phrasing and intonation. New York: Garland Publishing.

Frota, Sónia (2002a). 'Nuclear falls and rises in European Portuguese: a phonological analysis of declarative and question intonation', Probus 14 (Special issue on intonation in Romance, ed. by J. Ignacio Hualde), 113-146.

Frota, Sónia (2002b). 'Tonal association and target alignment in European Portuguese nuclear falls', in C. Gussenhoven, and N. Warner (eds.), Laboratory Phonology 7. Berlin/New York: Mouton de Gruyter, 387-418.

Frota, Sónia (2012-2015) (coord.). InAPoP - Interactive Atlas of the Prosody of Portuguese (Funded by FCT, PTDC/CLE-LIN/119787/2010).

http://www.fl.ul.pt/LaboratorioFonetica/InAPoP/.

Frota, Sónia (2014). 'The intonational phonology of European Portuguese', in S.A. Jun (ed.), Prosodic Typology II. The Phonology of Intonation and Phrasing. Oxford: Oxford University Press, 6-42.

Frota, Sónia, and Vigário, Marina (2000). 'Aspectos de prosódia comparada: ritmo e entoação no PE e no PB', in R. V. Castro, and P. Barbosa (eds.), Actas do XV Encontro da Associação Portuguesa de Linguística, Vol. I. Coimbra: APL, 533-555.

Frota, Sónia, and Vigário, Marina (2007). 'Intonational phrasing in two varieties of European Portuguese', in T. Riad, and C. Gussenhoven (eds.), Tones and Tunes, Vol. I. Berlin: Mouton de Gruyter, 265-291.

Gussenhoven, Carlos (2004). The Phonology of Tone and Intonation. Cambridge: Cambridge University Press.

Gussenhoven, Carlos (2007). Intonation. In Paul de Lacy (Ed.) The Cambridge Handbook of Phonology. Cambridge University Press. 253-280.

Halliday, M. A. K. (1967). Intonation and grammar in British English. The Hague: Mouton.

Jun, Sun-Ah (2005) (ed). Prosodic Typology. The Phonology of Intonation and Phrasing. Oxford: Oxford University Press.

Jun, Sun-Ah (2014) (ed). Prosodic Typology II. The Phonology of Intonation and Phrasing. Oxford: Oxford University Press. 
Krifka, Manfred (2007). 'Basic notions of information structure', in C. Féry, G. Fanselow, and M. Krifka (Eds.) The Notions of Information Structure, Interdisciplinary Studies on Information Structure. Potsdam: Universitätsverlag Potsdam , 13-55.

Ladd, D. Robert (2008). Intonational Phonology. 2nd ed. Cambridge: Cambridge University Press.

Lucente, L. (2012) Aspectos Dinâmicos da Fala e da Entoação no Português Brasileiro, Tese de Doutorado, Universidade de Campinas, São Paulo.

Mata, A. I. (1999). Para o estudo da entoação em fala espontânea e preparada no Português Europeu. Ph.D. dissertation, University of Lisbon.

Moraes, J. A. (1998) Intonation in Brazilian Portuguese. In: Hirst, D. and A. Di Cristo (eds.) Intonation Systems: a Survey of Twenty Languages, Cambridge: Cambridge University Press, 1998, pp. 179-194.

Moraes, J. A. (2003) Secondary stress in Brazilian Portuguese: perceptual and acoustical evidence. In: Proceedings of the XV International Congress of Phonetic Sciences, Barcelona, 3-9 August 2003, Glenelg North, Australia: Casual, pp. 20632066.

Moraes, J. A. (2006a) Variações em torno de tema e rema. Cadernos do CNLF [Cadernos do IX Congresso Nacional de Lingüística e Filologia] vol. IX, no. 17, pp. 279-289.

Moraes, J. A. (2006b) Melodic contours of yes/no questions in Brazilian Portuguese", Botinis, Antonis (ed.) Proceedings of ISCA Tutorial and Research Workshop on Experimental Linguistics, Athens: University of Athens, Greece, pp. 117-120.

Moraes, J. A. (2008) The Pitch Accents in Brazilian Portuguese: analysis by synthesis, In: Barbosa, P., Madureira, S. and Reis, C. (eds.) Speech Prosody 2008: Fourth Conference on Speech Prosody [Campinas, 6-9 May 2008], pp. 389-397.

Moraes, J. A. and Colamarco, M. (2007) Você está pedindo ou perguntando? Uma análise entonacional de pedidos e perguntas no Português do Brasil, Revista de Estudos da Linguagem, vol 15 (2), 2007, pp. 113-126.

Moraes, J. A. and Colamarco, M. (2008) Accommodation of intonational patterns in Brazilian Portuguese short utterances: compression or truncation? In Bisol, L. and Brescancini, C. (eds.) Contemporary Phonology in Brazil, Cambridge: Cambridge Scholars Publishing, pp. 2-21.

Moraes, J.A. and Rilliard, A. (2014) Illocution, attitudes and prosody: A multimodal analysis. In: Raso, T. and Mello, H. (eds.) Spoken Corpora and Linguistic Studies. Amsterdam: John Benjamins, pp. 233-270. 
Moraes, J. A. and Silva, H. (2011) A entoação de vocativos e apostos no Português do Brasil. In: Couto, L. e Lopes, C. R. (orgs.) As Formas de Tratamento em Português e em Espanhol; variação, mudança e funções conversacionais. Niterói: Editora da Universidade Federal Fluminense, 2011, pp. 103-124.

Nespor, M. and Vogel, I. (2007). Prosodic Phonology. Berlin/New York: Mouton de Gruyter (2nd edition).

Serra, Carolina (2009). Realização e percepção de fronteiras prosódicas no Português do Brasil: Fala espontânea e leitura. PhD dissertation. UFRJ.

Shattuck-Huffnagel, S. and Turk, A. (1996). A prosody tutorial for investigators of auditory sentence processing. Journal of Psycholinguistic Research 25, 193-247.

Silva, J. and S. Frota (2014). The intonation of yes-no question in three varieties of Brazilian Portuguese. Talk given at the 1st International Symposium on Variation in Portuguese. Braga: University of Minho (http://ww3.fl.ul.pt/LaboratorioFonetica/texts/Castelo_Frota_VarPor.pdf)

Tenani, Luciani E. (2002). Domínios prosódicos no Português do Brasil: implicações para a prosódia e para a aplicação de processos fonológicos. $\mathrm{PhD}$ dissertation. State University of Campinas.

Tenani, Luciani E., and Fernandes-Svartman, Flaviane (2008). 'Prosodic phrasing and intonation in neutral and subject-narrow-focus sentences of Brazilian Portuguese', Proceedings of Fourth Conference on Speech Prosody 2008. Campinas: RG/CNPq, 445-448.

Truckenbrodt, Hubert; Sandalo, Filomena, and Abaurre, Maria Bernadete (2009). 'Elements of Brazilian Portuguese Intonation', Journal of Portuguese Linguistics 8, 75-114.

Viana, M. C. (1987). Para a síntese da entoação do Português. Dissertação para acesso à categoria de Investigador Auxiliar. Lisboa: CLUL-INIC.

Vigário, M. (1998). Aspectos da Prosódia do Português Europeu: estruturas com advérbio de exclusão e negação frásica. Braga: CEHUM.

Vigário, Marina, and Fernandes-Svartman, Flaviane (2010). 'A atribuição de acentos tonais em compostos no Português do Brasil', in A. M. Brito, F. Silva, J. Veloso, and A. Fiéis (eds.), Textos Seleccionados - XXV Encontro da Associação Portuguesa de Linguística, Porto: Associação Portuguesa de Linguística, 769-786.

Vigário, Marina, and Frota, Sónia (2003). 'The intonation of Standard and Northern European Portuguese: a comparative intonational phonology approach', Journal of Portuguese Linguistics 2-2 (Special issue on Portuguese Phonology ed. by Wetzels), 115-137. 
Wagner, M. and Watson, Duane (2010). Experimental and theoretical advances in prosody: A review. Language and Cognitive Processes 25 (7/8/9). 905-945. 